Kocaeli Üniversitesi Sağlık Bilimleri Dergisi

\title{
PREDICTION OF MORTALITY, HOSPITALIZATION AND MECHANICAL VENTILATION NEEDS OF PATIENTS WITH PNEUMONIA IN COVID-19 OUTBREAK
}

\author{
COVID-19 SALGININDA PNÖMONISİ OLAN HASTALARDA MORTALITE, HASTANEYE YATIŞ VE \\ MEKANIK VENTILASYON GEREKSINIMLERININ DEĞERLENDIRILMESI
}

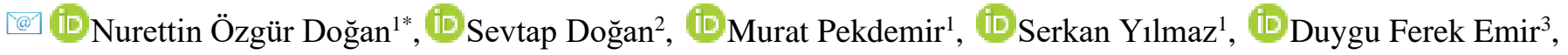 \\ Kutlu Barış Teke ${ }^{1}$
}

Kocaeli University, Faculty of Medicine, ${ }^{1}$ Department of Emergency Medicine; ${ }^{2}$ Department of Radiology; Kocaeli, Turkey; ${ }^{3}$ Başakşehir City Hospital, Department of Emergency Medicine, Istanbul, Turkey

ORCID iD: Nurettin Özgür Doğan: 0000-0002-5209-8076; Sevtap Doğan: 0000-0002-5862-6730; Murat Pekdemir: 0000-0002-3917-0192; Serkan Y1lmaz: 0000-0003-1496-6976; Duygu Ferek Emir: 0000-0002-4024-7468; Kutlu Barış Teke: 0000-0003-4161-7712

*Sorumlu Yazar / Corresponding Author: Nurettin Özgür Doğan, e-posta / e-mail: nurettinozgurdogan@ gmail.com

Geliş Tarihi / Received: 12.11 .2020

Kabul Tarihi / Accepted: 17.05 .2021

Yayım Tarihi / Published: 29.05.2021

\begin{abstract}
Objective: The COVID-19 pandemic has brought considerable loss to the world by means of pneumonia related mortality. In the current study, we aimed to discover the predictors of mortality and other worse outcomes in atypical pneumonia cases during the COVID-19 outbreak.

Methods: A prospective cohort study was carried out in our emergency department (ED) between March and May, 2020. All adult patients presented to the ED with atypical pneumonia patterns related to COVID-19 based on a chest CT scan were included in the study, and patients with bacterial pneumonia patterns were excluded. The primary outcome measure was determined as the composite outcome, including mortality and intensive care unit admission or mechanical ventilation needs within a one-month period. A binary logistic regression model was constructed to predict the worse outcomes in those patients.

Results: Of the 271 suspected pneumonia cases, 146 patients were included in the final analysis. The composite outcome occurred in 31 patients (21.2\%), 17 of whom died within one month. The patients' age, history of heart failure, history of stroke, body temperature, dyspnea, cough, altered mental status, serious bronchospasm, bilateral lung involvement, hemoglobin level, LDH, lactate level, and bicarbonate and creatinine levels were added to the final model. Finally, patients' altered mental status (OR:15.7, 95\%CI:1.7-141.6), serious bronchospasm (OR:12.4, 95\%CI:1.6-97.9), and lactate levels (OR:1.1, 95\% CI:1.0-1.2) were found to be independent predictors for worse outcomes.

Conclusion: Among various clinical and laboratory variables, altered mental status, serious bronchospasm, and lactate levels can be used to predict worse outcomes.
\end{abstract}

Keywords: COVID-19, pandemics, mortality, emergency department, pneumonia (MeSH Database)

$\ddot{O} \mathbf{z}$

Amaç: COVID-19 salgını, pnömoniye bağlı mortalite nedeniyle önemli kayıpları beraberinde getirmiştir. Bu araştırmada, COVID-19 salgını sırasında başvuran atipik pnömoni vakalarında mortalite ve diğer kötü sonlanım prediktörlerini bulmayı amaçladık.

Yöntem: Bu araştırma Mart ve Mayıs 2020 tarihleri arasında acil servisimizde yürütülen ileriye dönük kohort bir araştırmadır. Acil servise başvuran, toraks bilgisayarlı tomografisinde COVID-19 ilişkili atipik pnömoni patterni tespit edilen tüm erişkin hastalar araştırmaya dahil edildiler, bakteriyel pnömoni patterni olan hastalar ise dışlandılar. Araştırmanın primer sonlanım noktası; bir aylık süre içinde mortalite, yoğun bakım yatışı ve mekanik ventilasyon gereksinimi şeklinde birleşik sonlanım olarak planlandı. Bu hastalarda belirtilen kötü sonlanım prediktörlerinin araştırılması için bir lojistik regresyon modeli oluşturuldu.

Bulgular: Toplam 271 pnömoni olgusundan 146'sı son analize dahil edildi. Dahil edilen hastaların 31'inde (\%21,2) birleşik sonlanım gerçekleşti, 17 hasta bir aylık dönem içinde öldü. Son regresyon modeline hastaların yaşları, kalp yetmezliği öyküsü bulunması, inme öyküsü bulunması, vücut sıcaklığı, dispne, öksürük, bilinç değişikliği, ciddi bronkospazm, tomografide bilateral akciğer bulgusu olması, hemoglobin, LDH, laktat, bikarbonat ve kreatinin düzeyleri dahil edildi. Buna göre; hastalarda bilinç değişikliği olmasının (odds oranı [OO]:15,7, \%95'lik güven aralığı [GA]: 1,7-141,6), ciddi bronkospazmın (OO:12,4, \%95 GA:1,6-97,9) ve laktat düzeyindeki artışın (OO:1,1, \%95 GA: 1,0-1,2) kötü sonlanımın bağımsız prediktörleri olduğu bulundu.

Sonuç: Birçok klinik ve laboratuvar değişken arasından; bilinç değişikliği, ciddi bronkospazm ve laktat düzeylerinin kötü sonlanımı öngördüğü belirlenmiştir.

Anahtar Kelimeler: COVID-19, pandemi, mortalite, acil servis, pnömoni (MeSH veritabanına göre) 


\section{Introduction}

The coronavirus disease 2019 (COVID-19) rapidly became an important health concern that has a huge impact on emergency departments (EDs), intensive care units (ICUs), and other healthcare centers. According to the World Health Organization (WHO), the current situation has resulted in over 1,000,000 deaths worldwide. 1 Early data from China suggests that a majority of COVID-19 deaths occurred among older adults and among persons with serious underlying health conditions. ${ }^{2-3}$ However, after the disease spread all over the world, it has been suggested that many other variables can predict mortality and poor clinical outcome. .-8 $^{4-}$

Currently, it is known that the novel coronavirus can lead to a wide spectrum of conditions, from asymptomatic carriage to severe pulmonary disease. ${ }^{9,10}$ In addition, it is also known that the diagnosis of COVID-19 should be based on realtime polymerase chain reaction (PCR) tests whose sensitivity is not perfect. ${ }^{11,12}$ The WHO is currently only suggesting PCR testing for definitive diagnoses; however, the accuracy of PCR testing is likely to vary depending on the stage of the disease and the degree of viral dissemination or clearance. ${ }^{13}$ As repeat PCR testing may have additional benefits on diagnosis, the sensitivity of the PCR test was still $63 \%$ for nasal swabs and $32 \%$ for throat swabs. ${ }^{14}$

While this diagnostic challenge still persists, clinicians encountered cases of atypical pneumonia whose clinical signs and symptoms were indistinct. Accordingly, all patients having respiratory symptoms suggestive of atypical pneumonia were treated like COVID-19 pneumonia during this period. Thus, some authors argue that patient symptoms and computed tomography (CT) findings may help with early recognition and isolation of COVID-19 patients. ${ }^{15,16}$ Radiologist had high specificity (between 93\% and 100\%) and moderate sensitivity (between 67\% and 97\%) in distinguishing COVID-19 from viral pneumonia on chest CT. ${ }^{17}$ Whether patients are diagnosed with COVID-19 or not, severe and rapidly progressing atypical pneumonia cases were observed and presented to all EDs and other healthcare facilities during this period. In this study, we aimed to find the poor outcome predictors of atypical pneumonia cases by following the patients for one month.

\section{Methods}

\section{Study Design and Setting}

A single-center prospective cohort study was carried out in our academic ED between March and May, 2020. The study center is one of the pandemic hospitals approved by the government, which has an annual patient capacity of 60,000. Before the study began, an institutional review board approval was obtained and the patients were asked to read and sign an informed consent form.

\section{Selection of Participants}

All patients over 18 years with COVID-19 like atypical pneumonia who presented to the ED and agreed to participate were included in the study during the outbreak. All patients had symptoms suggesting pneumonia, and diagnoses were confirmed by CT scan. Patients were excluded if they had typical bacterial pneumonia patterns present in chest CT scans with lobar consolidation, dependent peribronchial infiltration with bronchial obstruction, or if the CT scan was consistent with aspiration pneumonia. In addition, patients were excluded if they refused to participate in the study or if we lost the patient during the follow-up period.

\section{Study Protocol}

All cases with suspected pneumonia who presented to the ED were evaluated by a senior emergency medicine resident regarding their pneumonia symptoms. If patients' symptoms were suggestive of pneumonia, a nasopharyngeal specimen for COVID-19 PCR testing was obtained in a specialized area near the ED, and patients underwent non-contrasted CT scanning. The demographic and disease characteristics included comorbidities, symptoms, physical examination findings, and vital signs of which were queried using standardized charts. Laboratory characteristics of the patients acquired by hospital database system. Chest CT images were evaluated and reported by a radiologist with ten years of experience in the field of chest CT imaging. The radiologist performed an interpretation of the $\mathrm{CT}$ images by considering the COVID-19 classification of the Radiological Society of North America (RSNA). ${ }^{18}$ COVID-19 pneumonia pattern was mainly established using the radiological criteria of RSNA when ground-glass opacities were combined with consolidations. All patients received hydroxychloroquine with or without azithromycine according to Turkish governmental guidelines on COVID-19 pneumonia. Care and treatments in the ICUs were not standardized and were left to the initiative of the caring physician. Patients were followed one month after the initial presentation to the ED. One month later, questions were directed to the patients about outcome measures via phone calls.

\section{Outcome Measures}

The primary outcome measures were determined as the composite outcome, including mortality, ICU admission, or mechanical ventilation needs within a one-month period. Accordingly, patients were classified into poor outcome (first group) or good outcome (second group) groups.

\section{Statistical Analysis}

All statistical analyses were performed using IBM SPSS Statistics for Windows (Version 20.0. Armonk, NY: IBM Corp.). The Kolmogorov-Smirnov test was used to test for a normal distribution of the continuous variables. The continuous variables were tested using the Student $t$ or Mann-Whitney U tests and were expressed as means (with standard deviation) and medians (with interquartile ranges [IQRs]). Categorical variables were tested using the Chisquare or Fisher's exact tests. A binary logistic regression model was created to evaluate the independent predictors of the primary composite outcome. Only variables that were statistically significant were included in the multivariate model. Prior to the establishment of the final model, a multicollinearity analysis was performed. The HosmerLemeshow test was used to assess the fitness of the model, and the effect sizes were expressed with odds ratios (ORs) and $95 \%$ confidence intervals (CIs). All the statistical analyses were two-sided. A $p$ value of $<0.05$ was considered to be the nominal level of significance.

\section{Results}

A total of 271 patients with suspected pneumonia were assessed for eligibility. Patients with bacterial pneumonia patterns $(n=27)$ and patients with other pathologies shown on the chest CT scan $(n=45)$ were excluded. No chest CT scan was obtained in 15 patients, and 38 patients had normal 
CT scan results. Ultimately, 146 patients were included in the final analysis (Figure 1).

Composite outcomes occurred in 31 patients (first group, $21.2 \%$ ), and 17 patients died within one month. No patients died or had mechanical ventilation needs in the second group, which consisted of 115 patients $(78.8 \%)$. The first group was older than the second group. In addition, congestive heart failure, stroke history, and tachypnea were more prominent in the first group. The body temperatures of the patients in the second group were higher than in the first group; however, they were in normal ranges for both groups (Table 1).

Regarding disease characteristics, the first group was more dyspneic compared to the second group. In addition, complaints including altered mental status, and bronchospasm were mostly seen in the first group. According to the chest CT scan results, bilateral lung involvement was more prominent in the first group (80.6\%) compared with the second group $(50.4 \%)(p=0.003)$ (Table 2 ). Only one patient reported contact with a confirmed COVID-19 case $(3.2 \%)$ in the first group; however, 27 cases $(23.5 \%)$ had contact with patients participating in the second group ( $p=0.011)$. Lactate, lactate dehydrogenase, BUN, and creatinine were higher in the first group, whereas hemoglobin, $\mathrm{pH}$, and bicarbonate levels were lower in this group. Laboratory values seemed to be within normal ranges, although statistically significant differences were observed between the groups for some variables (Table 3).

Before the multivariate logistic regression analysis was carried out, a multicollinearity analysis was conducted for correlated variables at the $r>0.5$ level. Regarding this analysis, BUN and creatinine values had a strong correlation $(\mathrm{r}=0.709)$; thus, creatinine was added to the final model. In addition, bicarbonate was added to the model instead of $\mathrm{pH}$ level. Ultimately, age, history of heart failure, history of stroke, body temperature, dyspnea, cough, altered mental status, serious bronchospasm, bilateral lung involvement, hemoglobin levels, LDH, lactate levels, bicarbonate, and creatinine levels were added to the final model.

Regarding the final analysis, patients' altered mental status (OR:15.7, 95\% CI: 1.7 to 141.6), serious bronchospasm (OR: $12.4,95 \%$ CI: 1.6 to 97.9), and lactate levels (OR: 1.1, $95 \%$ CI: 1.0 to 1.2 ) were found to be independent predictors for worse outcomes in those patients. The result of the Hosmer-Lemeshow test was 0.300, and the model was accepted as a fit.

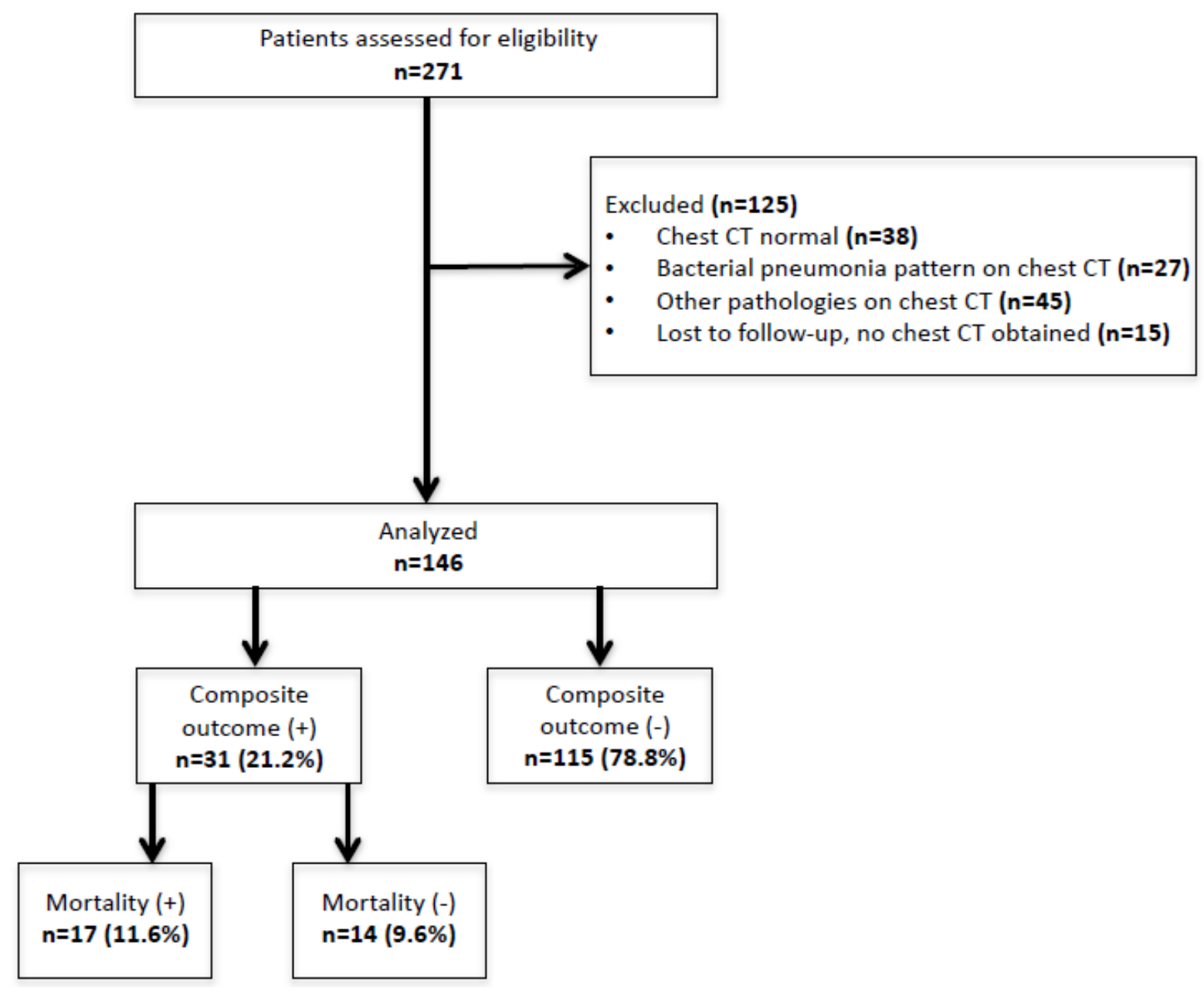

Figure 1. Patient flow chart 
Table 1. Baseline characteristics, comorbidities and vital signs of the study population

\begin{tabular}{|c|c|c|c|}
\hline & Group 1 & Group 2 & \\
\hline & $\begin{array}{l}\text { Composite outcome } \\
\text { occurred }(n=31)\end{array}$ & $\begin{array}{l}\text { Composite outcome did } \\
\text { not occurred }(\mathrm{n}=115)\end{array}$ & $p$ value \\
\hline Age, year (median, IQR) & $68(56-80)$ & $57(39-71)$ & 0.015 \\
\hline Male (n,\%) & $18(58.1 \%)$ & $61(53.0 \%)$ & 0.619 \\
\hline Diabetes mellitus (n,\%) & $10(32.3 \%)$ & $28(24.3 \%)$ & 0.373 \\
\hline Hypertension (n,\%) & $17(54.8 \%)$ & $43(37.4 \%)$ & 0.080 \\
\hline Congestive heart failure (n, \%) & $9(29.0 \%)$ & $13(11.3 \%)$ & 0.022 \\
\hline Chronic kidney disease (n, \%) & $4(12.9 \%)$ & $11(9.6 \%)$ & 0.524 \\
\hline Previous stroke (n, \%) & $8(25.8 \%)$ & $6(5.2 \%)$ & 0.002 \\
\hline $\operatorname{Asthma~(n,\% )~}$ & $3(9.7 \%)$ & $14(12.2 \%)$ & 1.000 \\
\hline $\operatorname{COPD}(\mathrm{n}, \%)$ & $3(9.7 \%)$ & $11(9.6 \%)$ & 1.000 \\
\hline Interstitial lung disease (n,\%) & $0(0.0 \%)$ & $1(0.9 \%)$ & 1.000 \\
\hline Cancer (n, \%) & $4(12.9 \%)$ & $14(12.2 \%)$ & 1.000 \\
\hline \multicolumn{4}{|l|}{ Vital signs } \\
\hline Temperature, ${ }^{\circ} \mathrm{C}$ & $36.4(36.0-36.8)$ & $36.6(36.2-37.2)$ & 0.029 \\
\hline Pulse, beat/min & $95(85-114)$ & $97(82-108)$ & 0.769 \\
\hline Systolic blood pressure, $\mathrm{mmHg}$ & $125(104-141)$ & $133(113-148)$ & 0.118 \\
\hline Diastolic blood pressure, $\mathrm{mmHg}$ & $73(60-88)$ & $79(69-90)$ & 0.207 \\
\hline Respiratory rate, breath/min & $25(22-31)$ & $22(20-26)$ & 0.025 \\
\hline Saturation, \% & $94(87-98)$ & $96(94-98)$ & 0.059 \\
\hline
\end{tabular}

IQR: Interquartile range, N/A: Non applicable 
Table 2. Disease characteristics of atypical pneumonia cases

\begin{tabular}{|c|c|c|c|}
\hline & $\begin{array}{l}\text { Group } 1 \\
(n=31)\end{array}$ & $\begin{array}{l}\text { Group } 2 \\
(n=115)\end{array}$ & $p$ value \\
\hline Duration of symptoms (days, median, IQR) & $3(2-8)$ & $3(2-6)$ & 0.356 \\
\hline Positive COVID-19 PCR result (n, \%) & $8(25.8 \%)$ & $37(32.2 \%)$ & 0.496 \\
\hline Travel to abroad $(\mathrm{n}, \%)$ & $1(3.2 \%)$ & $0(0.0 \%)$ & N/A \\
\hline Active pregnancy (n, \%) & $0(0.0 \%)$ & $1(0.9 \%)$ & N/A \\
\hline History of fever (n, \%) & $11(35.5 \%)$ & $51(44.3 \%)$ & 0.376 \\
\hline Dyspnea $(\mathrm{n}, \%)$ & $19(61.3 \%)$ & $42(36.5 \%)$ & 0.013 \\
\hline Cough $(\mathrm{n}, \%)$ & $11(35.5 \%)$ & $70(60.9 \%)$ & 0.012 \\
\hline Sputum $(n, \%)$ & $5(16.1 \%)$ & $12(10.4 \%)$ & 0.360 \\
\hline Myalgia (n, \%) & $5(16.1 \%)$ & $29(25.2 \%)$ & 0.288 \\
\hline Nausea $(n, \%)$ & $6(19.4 \%)$ & $19(16.5 \%)$ & 0.710 \\
\hline Chest pain $(\mathrm{n}, \%)$ & $1(3.2 \%)$ & $11(9.6 \%)$ & 0.462 \\
\hline Altered mental status (n,\%) & $10(32.3 \%)$ & $3(2.6 \%)$ & $<0.001$ \\
\hline Diarrhea $(\mathrm{n}, \%)$ & $1(3.2 \%)$ & $6(5.2 \%)$ & 1.000 \\
\hline Sore throat $(\mathrm{n}, \%)$ & $0(0.0 \%)$ & $8(7.0 \%)$ & 0.203 \\
\hline Headache $(\mathrm{n}, \%)$ & $0(0.0 \%)$ & $3(2.6 \%)$ & 1.000 \\
\hline Nasal discharge $(\mathrm{n}, \%)$ & $0(0.0 \%)$ & $1(0.9 \%)$ & 1.000 \\
\hline \multicolumn{4}{|l|}{ Physical Examination } \\
\hline Throat congestion ( $\mathrm{n}, \%)$ & $2(6.5 \%)$ & $9(7.9 \%)$ & 1.000 \\
\hline Rales (n, \%) & $10(32.3 \%)$ & $27(23.7 \%)$ & 0.332 \\
\hline Ronchus (n, \%) & $2(6.5 \%)$ & $16(14.0 \%)$ & 0.363 \\
\hline Serious bronchospasm $(\mathrm{n}, \%)$ & $9(29.0 \%)$ & $2(1.7 \%)$ & $<0.001$ \\
\hline Peripheral edema $(n, \%)$ & $4(12.9 \%)$ & $10(8.8 \%)$ & 0.499 \\
\hline \multicolumn{4}{|l|}{ Radiological features } \\
\hline Peripheral GGO $(\mathrm{n}, \%)$ & $18(58.1 \%)$ & $54(47.0 \%)$ & 0.272 \\
\hline Multifocal GGO $(\mathrm{n}, \%)$ & $10(32.3 \%)$ & $20(17.4 \%)$ & 0.069 \\
\hline Bilateral lung involvement (n, \%) & $25(80.6 \%)$ & $58(50.4 \%)$ & 0.003 \\
\hline
\end{tabular}

GGO: Ground-glass opacity 
Table 3. Baseline laboratory values of patients on presentation in emergency department

\begin{tabular}{|c|c|c|c|}
\hline & $\begin{array}{l}\text { Group } 1 \\
(\mathbf{n}=31)\end{array}$ & $\begin{array}{l}\text { Group } 2 \\
(n=115)\end{array}$ & $p$ value \\
\hline Hemoglobin, g/dL & $11.3 \pm 2.8$ & $12.5 \pm 2.3$ & 0.014 \\
\hline Leukocyte, $10^{3} / \mu \mathrm{L}$ & $8600(6000-13100)$ & $7550(5300-10300)$ & 0.129 \\
\hline Neutrophil, $10^{3} / \mu \mathrm{L}$ & $5900(3800-7400)$ & $5450(3375-8400)$ & 0.535 \\
\hline Lymphocyte, $10^{3} / \mu \mathrm{L}$ & $1300(700-2200)$ & $1100(800-1625)$ & 0.236 \\
\hline Neutrophil / Lymphocyte ratio & $4.1(2.2-9.6)$ & $4.2(2.5-9.1)$ & 0.725 \\
\hline C-reactive protein, $\mathrm{mg} / \mathrm{L}$ & $29(13-126)$ & $23(7-90)$ & 0.179 \\
\hline Increased procalcitonin* & $7(29.2 \%)$ & $23(22.1 \%)$ & 0.462 \\
\hline LDH, U/L & $296(225-587)$ & $259(202-356)$ & 0.034 \\
\hline D-dimer, mg/L & $1.8(0.5-5.1)$ & $0.7(0.3-2.1)$ & 0.054 \\
\hline Lactate, $\mathrm{mg} / \mathrm{dL}$ & $18.0(12.5-27.0)$ & $14.0(10.0-18.0)$ & 0.027 \\
\hline pH & $7.37(7.33-7.41)$ & $7.40(7.35-7.42)$ & 0.020 \\
\hline $\mathrm{HCO3}, \mathrm{mEq} / \mathrm{L}$ & $22.7(18.7-24.5)$ & $24.0(22.1-26.4)$ & 0.006 \\
\hline $\mathrm{Na}, \mathrm{mEq} / \mathrm{L}$ & $135(131-140)$ & $137(135-140)$ & 0.114 \\
\hline $\mathbf{K}, \mathbf{m E q} / \mathbf{L}$ & $4.4(3.8-5.1)$ & $4.2(3.9-4.6)$ & 0.174 \\
\hline AST, U/L & $32(20-57)$ & $26(20-46)$ & 0.375 \\
\hline BUN, mg/dL & $22(14-41)$ & $17(12-25)$ & 0.009 \\
\hline Creatinine, mg/dL & $1.1(0.6-1.5)$ & $0.8(0.6-1.0)$ & 0.013 \\
\hline
\end{tabular}

*: Procalcitonin level above $0.25 \mathrm{ng} / \mathrm{mL}, \mathrm{LDH}$ : Lactate dehydrogenase

Table 4. Multivariate logistic regression analysis to determine worse composite outcome in atypical pneumonia case

\begin{tabular}{llll}
\hline & Wald & OR (95\% CI) & $p$ value \\
\hline Age & 0.03 & $1.00(0.96$ to 1.04$)$ & 0.872 \\
Heart failure & 2.62 & $3.82(0.75$ to 19.36$)$ & 0.106 \\
History of stroke & 1.53 & $3.29(0.50$ to 21.69$)$ & 0.217 \\
Body temperature & 1.94 & $0.55(0.23$ to 1.28$)$ & 0.164 \\
Respiratory rate & 3.52 & $0.87(0.75$ to 1.01$)$ & 0.061 \\
Dyspnea & 0.09 & $1.24(0.31$ to 4.93$)$ & 0.764 \\
Cough & 0.01 & $0.93(0.24$ to 3.62$)$ & 0.913 \\
Altered mental status & 6.03 & $\mathbf{1 5 . 7 2}(\mathbf{1 . 7 4}$ to 141.61$)$ & $\mathbf{0 . 0 1 4}$ \\
Serious bronchospasm & 5.71 & $\mathbf{1 2 . 4 1}(\mathbf{1 . 5 7}$ to $\mathbf{9 7 . 9 3})$ & $\mathbf{0 . 0 1 7}$ \\
Bilateral lung involvement & 1.84 & $2.88(0.62$ to 13.25$)$ & 0.175 \\
Hemoglobin & 1.29 & $0.84(0.62$ to 1.14$)$ & 0.256 \\
LDH & 0.07 & $1.00(1.00$ to 1.00$)$ & 0.799 \\
Lactate & 5.74 & $\mathbf{1 . 1 0}(\mathbf{1 . 0 2}$ to 1.19$)$ & $0.89(0.73$ to 1.08$)$ \\
Bicarbonate & 1.35 & $0.80(0.48$ to 1.32$)$ & $\mathbf{0 . 0 1 7}$ \\
Creatinine & 0.79 & 0.246
\end{tabular}




\section{Discussion}

COVID-19 has a significant impact on the healthcare system both in direct and indirect ways. One of the possible mechanisms of this indirect impact is the large size of undiagnosed severe COVID-19 cases and the reduced access to healthcare due to the disruption of the normal working processes. ${ }^{19}$ Diagnostic challenges also complicate the selection of patients with poor health outcomes. Under these circumstances, mortality cohorts can be a method used to recognize patients who will use the healthcare system more, as well as to identify which patients' health conditions may worsen. In our study, we intended to establish a composite outcome that included mortality, ICU care, and the need for mechanical ventilation. Although there was a statistically significant difference between the two groups in terms of clinical and laboratory variables, this difference did not correspond to the clinical significance for many aspects.

Recently, a prospective cohort study determining predictors of mortality for patients with COVID-19 was published.6 In this study, age, preexisting concurrent cardiovascular or cerebrovascular diseases, CD3 $+\mathrm{CD} 8+\mathrm{T}$ cells $\leq 75$ cell $/ \mu \mathrm{L}$, and cardiac troponin $\mathrm{I} \geq 0.05 \mathrm{ng} / \mathrm{mL}$ were determined as factors that increase the risk of mortality for patients with COVID-19. According to Ruan et al., the predictors for fatal COVID-19 outcomes include age, the presence of underlying diseases, the presence of secondary infection, and elevated inflammatory indicators in the blood. 8 Zhou et al. also retrospectively evaluated the predictors of inhospital deaths in a Chinese COVID-19 population. According to this study, older age, higher Sequential Organ Failure Assessment (SOFA) scores, and a D-dimer greater than $1 \mu \mathrm{g} / \mathrm{mL}$ on admission could help clinicians identify patients with poor prognosis at an early stage..$^{20}$

Most of the aforementioned studies only dealt with PCRpositive patients without taking into account pneumonic involvement. Among them, Du et al. described a COVID-19 pneumonia cohort consisting of 179 patients having positive or negative PCR results similar to our study. ${ }^{6}$ They collected data prospectively; however, the time interval for mortality was not specified. Similar to their study, we found that increased age and the existence of cardiovascular comorbidities, including heart failure and stroke history, renal involvement, dyspnea, and tachypnea were more prevalent in the poor outcome group. They did not report lactate levels or physical examination findings, such as bronchospasm, which were found to be predictors of poor health outcomes in our study. It should be noted that increased respiratory rates and oxygen requirements at initial admission were the most important determinants of the severity of the disease, and those variables were significant predictors of clinical deterioration. ${ }^{4,5}$

Previous studies have highlighted the effects of increased age and many comorbid diseases in COVID-19 related mortality and morbidity. ${ }^{8,21,22}$ Furthermore, cardiovascular comorbidities, including hypertension and renal involvement, also play an important role in assessing the severity of the disease. ${ }^{4,21,23}$ A large retrospective cohort from New York City claimed that patients admitted to ICUs were older, predominantly male $(78.0 \%)$, had developed acute kidney injury, and $35.2 \%$ needed dialysis. ${ }^{24}$ Hypertension was the leading comorbidity in the ICU group in this study with a frequency of $66.9 \%$; this ratio was also higher in our poor outcome group $(54.8 \%)$. This finding was followed by congestive heart failure in this study $(10.2 \%)$, which was more prevalent in the poor outcome group $(29.0 \%)$.

In this study, we found that two variables that remind us of the criteria related to sepsis can be valuable for COVID-19 related pneumonia. Moreover, patients' altered mental status was accepted as one of the determinants of quick SOFA criteria, and lactate was an essential part of septic shock evaluation. ${ }^{25}$ Considering that these criteria are independent predictors of clinical deterioration in our study, it can be interpreted that COVID-19 related atypical pneumonia may correspond to sepsis related processes in the advanced stages of the disease.

\section{Limitations}

Our study has several limitations. First, this study was a single-center experience of COVID-19 pneumonia cases with a relatively small sample size. Thus, the generalizability of our results is limited. Second, some patients had secondary PCR testing, whereas others did not. As previously discussed, the results of PCR testing are timesensitive and mostly related to a swab technique. Therefore, the number of patients with positive PCR tests may actually be higher. Third, patients received different treatments after their initial visit to the ED, and we cannot follow patients' compliance with treatments. However, treatment regimens were mostly already set by the government's scientific guidelines for COVID-19, of which many and all physicians try to adhere to.

\section{Conclusion}

During the COVID-19 outbreak, many patients were subjected to PCR testing to establish an exact diagnosis. However, the recognition of atypical pneumonia patients with poor clinical outcomes may provide clinicians with greater benefits in daily practice. Furthermore, patients' altered mental status, serious bronchospasm, and increases in lactate levels were found to be independent predictors for worse healthcare outcomes for those patients. Future studies may involve the prognostic value of other sepsis criteria for severe COVID-19 related pneumonia.

\section{Conflict of Interest}

None declared

\section{Author Contributions}

NÖD, SD, MP: Design; NÖD, SD, MP: Project development; DFE, KBT, NÖD: Data collection; KG, BA, NÖD, MP: Analysis; NÖD, MP, SY: Literature search; KG, NÖD, SD, MP: Manuscript writing; MP, SY, SD, NÖD: Critical review

\section{References}

1. World Health Organization. Coronavirus (COVID-19) outbreak situation. URL: https://www.who.int/emergencies/diseases/novel-coronavirus2019 (Accessed on: October 15, 2020).

2. Yang X, Yu Y, Xu J, Shu H, Xia J, Liu H, et al. Clinical course and outcomes of critically ill patients with SARS-CoV2 pneumonia in Wuhan, China: a single-centered, retrospective, observational study. Lancet Respir Med 2020;8:475-481.

3. Chen N, Zhou M, Dong X, Qu J, Gong F, Han Y, et al. Epidemiological and clinical characteristics of 99 cases of 2019 novel coronavirus pneumonia in Wuhan, China: a descriptive study. Lancet 2020;395:507-513.

4. Bhargava A, Fukushima EA, Levine M, Zhao W, Tanveer F, Szpunar SM, et al. Predictors for Severe COVID-19 Infection. 
Clin Infect Dis 2020 May 30;ciaa674. doi: $10.1093 / \mathrm{cid} / \mathrm{ciaa} 674$. Online ahead of print.

5. Cecconi M, Piovani D, Brunetta E, Aghemo A, Greco M, Ciccarelli M, et al. Early Predictors of Clinical Deterioration in a Cohort of 239 Patients Hospitalized for Covid-19 Infection in Lombardy, Italy. J Clin Med 2020;9:E1548.

6. Du RH, Liang LR, Yang CQ, Wang W, Cao TZ, Li M, et al. Predictors of Mortality for Patients With COVID-19 Pneumonia Caused by SARS-CoV-2: A Prospective Cohort Study. Eur Respir J 2020;55:2000524.

7. Petrilli CM, Jones SA, Yang J, Rajagopalan H, O'Donnell L, Chernyak Y, et al. Factors Associated With Hospital Admission and Critical Illness Among 5279 People With Coronavirus Disease 2019 in New York City: Prospective Cohort Study. BMJ 2020;369:m1966.

8. Ruan Q, Yang K, Wang W, Jiang L, Song J. Clinical Predictors of Mortality Due to COVID-19 Based on an Analysis of Data of 150 Patients From Wuhan, China. Intensive Care Med 2020;46:846-848.

9. Rothe C, Schunk M, Sothmann P, Bretzel G, Froeschl G, Wallrauch C, et al. Transmission of 2019-nCoV Infection From an Asymptomatic Contact in Germany. $N$ Engl J Med 2020;382:970-971.

10. Guan WJ, Ni ZY, Hu Y, Liang WH, Ou CQ, Heet JX, et al. Clinical Characteristics of Coronavirus Disease 2019 in China. N Engl J Med 2020;382:1708-1720.

11. Zhao J, Yuan Q, Wang H, Liu W, Liao X, Suet Y, et al. Antibody responses to SARS-CoV-2 in patients of novel coronavirus disease 2019. Clin Infect Dis 2020. DOI: $10.1093 / \mathrm{cid} / \mathrm{ciaa} 344$.

12. Sethuraman N, Jeremiah SS, Ryo A. Interpreting Diagnostic Tests for SARS-CoV-2. JAMA [In Press] 2020 May 6. doi: 10.1001/jama.2020.8259.

13. Watson J, Whiting PF, Brush JE. Interpreting a COVID-19 Test Result. BMJ 2020;369:m1808.

14. Wang W, Xu Y, Gao R, Lu R, Han K, Wu G, et al. Detection of SARS-CoV-2 in Different Types of Clinical Specimens. JAMA 2020;323:1843-1844.

15. Ye Z, Zhang Y, Wang Y, Huang Z, Song B. Chest CT manifestations of new coronavirus disease 2019 (COVID-19): a pictorial review. Eur Radiol 2020;30:4381-4389.

16. Ai T, Yang Z, Hou H, Zhan C, Chen C, Lv W, et al. Correlation of Chest CT and RT-PCR Testing in Coronavirus Disease 2019 (COVID-19) in China: A Report of 1014 Cases. Radiology 2020;296:E32-E40.

17. Bai HX, Hsieh B, Xiong Z, Halsey K, Choi JW, Tran TML, et al. Performance of Radiologists in Differentiating COVID-19 From Viral Pneumonia on Chest CT. Radiology 2020;296:E46-E54.

18. Simpson S, Kay FU, Abbara S, et al. Radiological Society of North America Expert Consensus Statement on Reporting Chest CT Findings Related to COVID-19. J Thorac Imaging. 2020 Mar 25. [In Press] doi: 10.1148/ryct.2020200152

19. Magnani C, Azzolina D, Gallo E, Ferrante D, Gregori D. How Large Was the Mortality Increase Directly and Indirectly Caused by the COVID-19 Epidemic? An Analysis on AllCauses Mortality Data in Italy. Int $J$ Environ Res Public Health 2020;17:E3452.

20. Zhou F, Yu T, Du R, Fan G, Liu Y, Liu Z, et al. Clinical Course and Risk Factors for Mortality of Adult Inpatients With COVID-19 in Wuhan, China: A Retrospective Cohort Study. Lancet 2020;395:1054-1062.

21. Aggarwal S, Garcia-Telles N, Aggarwal G, Lavie C, Lippi G, Henry BM, et al. Clinical Features, Laboratory Characteristics, and Outcomes of Patients Hospitalized With Coronavirus Disease 2019 (COVID-19): Early Report From the United States. Diagnosis 2020;7:91-96.

22. Hong KS, Lee KH, Chung JH, Shin KC, Choi EY, Jin HJ, et al. Clinical Features and Outcomes of 98 Patients Hospitalized With SARS-CoV-2 Infection in Daegu, South Korea: A Brief Descriptive Study. Yonsei Med J 2020;61:431437.

23. Imam Z, Odish F, Gill I, O'Connor D, Armstrong J, Vanood $\mathrm{A}$, et al. Older Age and Comorbidity Are Independent
Mortality Predictors in a Large Cohort of 1305 COVID-19 Patients in Michigan, United States. J Intern Med 2020 Jun 4. doi: 10.1111/joim.13119. Online ahead of print.

24. Argenziano MG, Bruce SL, Slater CL, Tiao JR, Baldwin MR, Barr RG, et al. Characterization and Clinical Course of 1000 Patients With Coronavirus Disease 2019 in New York: Retrospective Case Series. BMJ 2020;369:m1996.

25. Singer M, Deutschman CS, Seymour CW, Shankar-Hari M, Annane D, Bauer M, et al. The Third International Consensus Definitions for Sepsis and Septic Shock (Sepsis-3). JAMA 2016;315:801-10. 